OPEN

SUBJECT AREAS:

PALAEONTOLOGY

VOLCANOLOGY

Received

1 October 2014

Accepted

15 December 2014

Published

22 January 2015

Correspondence and requests for materials should be addressed to V.R.T. (valentin.troll@ geo.uu.se)

\title{
Nannofossils in 2011 El Hierro eruptive products reinstate plume model for Canary Islands
}

\author{
Kirsten Zaczek1, Valentin R. Troll 1,2, Mario Cachao ${ }^{3}$, Jorge Ferreira ${ }^{3}$, Frances M. Deegan' , \\ Juan Carlos Carracedo ${ }^{2}$, Vicente Soler ${ }^{4}$, Fiona C. Meade ${ }^{1} \&$ Steffi Burchardt ${ }^{1}$
}

\footnotetext{
'Uppsala University, Dept. of Earth Sciences, Centre for Experimental Mineralogy, Petrology and Geochemistry (CEMPEG), Uppsala, Sweden, ${ }^{2}$ University of Las Palmas de Gran Canaria, Dept. of Physics (GEOVOL), Las Palmas de Gran Canaria, Spain, ${ }^{3}$ University of Lisbon, Faculty of Sciences, Dept. and Centre of Geology, Portugal, ${ }^{4}$ Estacion Volcanologica de Canarias, IPNA-CSIC, La Laguna, Tenerife, Spain.
}

The origin and life cycle of ocean islands have been debated since the early days of Geology. In the case of the Canary archipelago, its proximity to the Atlas orogen led to initial fracture-controlled models for island genesis, while later workers cited a Miocene-Quaternary east-west age-progression to support an underlying mantle-plume. The recent discovery of submarine Cretaceous volcanic rocks near the westernmost island of El Hierro now questions this systematic age-progression within the archipelago. If a mantle-plume is indeed responsible for the Canaries, the onshore volcanic age-progression should be complemented by progressively younger pre-island sedimentary strata towards the west, however, direct age constraints for the westernmost pre-island sediments are lacking. Here we report on new age data obtained from calcareous nannofossils in sedimentary xenoliths erupted during the 2011 El Hierro events, which date the sub-island sedimentary rocks to between late Cretaceous and Pliocene in age. This age-range includes substantially younger pre-volcanic sedimentary rocks than the Jurassic to Miocene strata known from the older eastern islands and now reinstate the mantle-plume hypothesis as the most plausible explanation for Canary volcanism. The recently discovered Cretaceous submarine volcanic rocks in the region are, in turn, part of an older, fracture-related tectonic episode.

nteraction between a stationary mantle plume and an overriding tectonic plate has been a popular concept to explain linear volcanic island chains in the last few decades ${ }^{1,2,3}$. Mantle plumes are predicted to produce an ageprogression along the island chain due to gradual plate movement, as classically demonstrated for the Hawaiian islands ${ }^{1}$. In line with this hypothesis, an age progression has also been proposed for the Canary Islands $s^{2,3,4}$, but the classic mantle-plume model has not been fully accepted for the Canary archipelago ${ }^{5,6,7}$. An independent test for plume-induced volcanism would be a concurrent younging of the sedimentary strata underlying the island chain, however, in the Canaries, detailed evidence of the sedimentary record is presently restricted to the east and central part of the archipelago ${ }^{8-14}$. Bathymetric and seismic reflection studies suggest that up to $8 \mathrm{~km}$ of sediment exists below the Eastern Canaries, whereas only 0.5 to $1 \mathrm{~km}$ of sedimentary strata underlie the west of the archipelago ${ }^{15-18}$. However, direct age information on the pre-island sedimentary rocks from under the westernmost and presumably youngest islands of El Hierro and La Palma has been critically lacking so far.

The most recent eruption in the Canary Islands commenced in October 2011 along the southern submarine rift zone of El Hierro and lasted until March 2012 ( 2 km offshore, with vent depths ranging from $\sim 350$ to $100 \mathrm{~m}$ bsl. ${ }^{19,20}$; Figure 1). Just prior to the eruption, magma migrated laterally via a temporary shallow reservoir at a depth of $\sim 4.5$ to $5 \mathrm{~km}$, which coincides with the level of pre-island sediments ${ }^{17,18,21,22}$. Lateral magma transport for several $\mathrm{km}$ along this sedimentary interface allowed ample time for interaction between magma and the preisland sedimentary rocks underneath El Hierro, with abundant sedimentary xenoliths subsequently erupted, but notably restricted to the first week of the 2011 activity $^{21,23}$. The sedimentary xenoliths (Appendix A) were contained in 'floating stones' of up to soccer ball size that consisted of dominantly light-coloured pumiceous glass coated with basanite, which we have termed 'xeno-pumice' ${ }^{19,20,23}$. El Hierro xeno-pumice contain a mineral assemblage of quartz, mica, clay minerals illite and smectite, jasper, gypsum, calcite, and halite ${ }^{23}$, and thus resemble remelted, continentally-derived marine sedimentary compositions. Neither the surviving sedimentary relicts nor their host xeno-pumice samples display traces of volcanic detritus, unlike recent flank sediment 


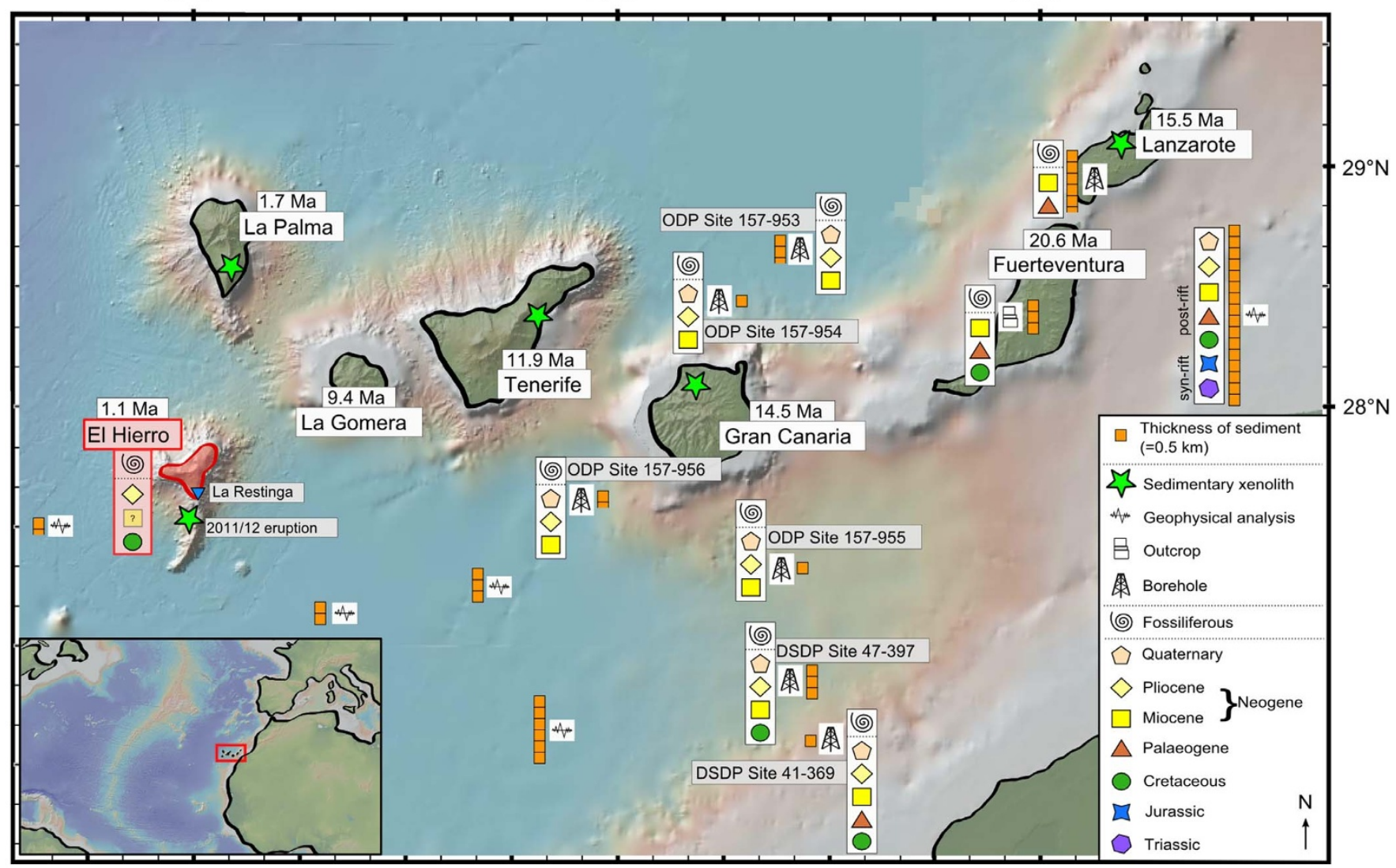

Figure $1 \mid$ Map of the Canary archipelago with ages of oldest volcanic rocks, occurrence of sedimentary relicts ("xenoliths", see also Appendix E), thickness of sedimentary layers and deterministic techniques indicated. The sedimentary package underneath the eastern Canaries is well characterised from onshore exposure, drilling campaigns and seismic investigations ${ }^{3,4,8-11,14,15,17,23,26,31-41}$, while the age and nature of the sedimentary strata underneath the western Canaries is unknown. The eruption of nannofossil-bearing sedimentary relicts at the westernmost island of El Hierro in 2011 now defines the age range of the sedimentary layers beneath El Hierro to between Cretaceous and Pliocene. The map was created using "GeoMapApp" (www.geomapapp. org $)^{42}$.

dredged from the slopes of the southern ridge of El Hierro ${ }^{23}$, implying that the sedimentary relicts are pre-island in origin. These sedimentary xenoliths survived transport from depth due to efficient gas loss and rapid ascent (Appendix B), and now provide us with the first direct evidence of pre-volcanic El Hierro sedimentary strata.

After inspection of $>300$ xeno-pumice specimens, 14 were selected for detailed study (Appendix A) and prepared for identification of their nannofossil content using optical petrographic microscopy. Calcareous nannofossils were recognized in 50\% of the investigated sedimentary relicts and comprise mainly coccolithophores, which are one of the major open ocean phytoplankton groups. Coccolithophores secrete small calcite platelets, the coccoliths, which aggregate to form a calcareous shell (coccosphere) around a living cell. Their geological record extends back to the Upper Triassic and shows rapid evolutionary diversification, but also significant extinctions, making them a reliable stratigraphic biomar$\mathrm{ker}^{24}$. For the purpose of this work, all identifiable parts of coccolith specimens were included in the count (Appendix C). Taxonomic identification of coccoliths followed established classification schemes ${ }^{24,25}$. Most of the coccoliths in El Hierro sedimentary relicts reveal overgrowth and a degree of recrystallization, and the assemblage is overall poorly preserved. Nevertheless, a total of 13 distinct taxa were determined, reflecting a relatively low diversity, but several samples permitted identification to the genus and species level. Four of seven fossil-bearing samples share an age compatible assemblage comprising: Prediscosphaera sp., Prediscosphaera cretacea, Retecapsa sp., Retecapsa crenulata, Watznaueria sp., Watznaueria fossacincta,
Watznaueria ovata, Watznaueria barnesiae, Watznaueria manivitiae, Bukrylithus ambiguus, Eiffellithus turriseiffelii, Eprolithus floralis, and Rhagodiscus asper. These taxa have a common temporal range in the Cenomanian and thus define the larger group of fossil-bearing sedimentary relicts as Upper Cretaceous in age. This age range is consistent with that of the $>8 \mathrm{~km}$ thick Jurassic to Miocene sedimentary successions under the eastern Canary Islands, known e.g., from the Fuerteventura basal complex and from the Deep Sea Drilling Project (DSDP) holes 41-369 and 47-397 to the southeast of Gran Canaria $^{8-10,12}$ (Figure 1). Two of seven El Hierro samples, in turn, contain the distinct coccolith assemblage of Reticulofenestra spp., Umbilicosphaera sibogae, and Umbellosphaera tenuis exclusively, whose common temporal range is the Pliocene (Figure 2). A single sample, however, shows a mixed age assemblage that includes both Cretaceous and Pliocene species (4-EH-XP; Figure 2) and either represents sedimentary reworking or, more likely, physical mixing of sedimentary materials during interaction with magma in the conduit. Notably, no species younger than Maastrichtian are found in the purely Cretaceous samples (Figure 2), ruling out contamination from recent seafloor sediment or the water column during transport to the sea surface.

The older nannofossil assemblage therefore dates back to the mid Cretaceous (Albian/Cenomanian transition), with an absolute age of $\sim 100 \mathrm{Ma}$ (Figure 2). The occurrence of Umbellosphaera tenius and Ubilicosphaera sibogae in the younger age group, in turn, suggest a Pliocene to Quaternary age for the youngest sedimentary rocks beneath El Hierro. Their association with Reticulofenestra spp. indi- 


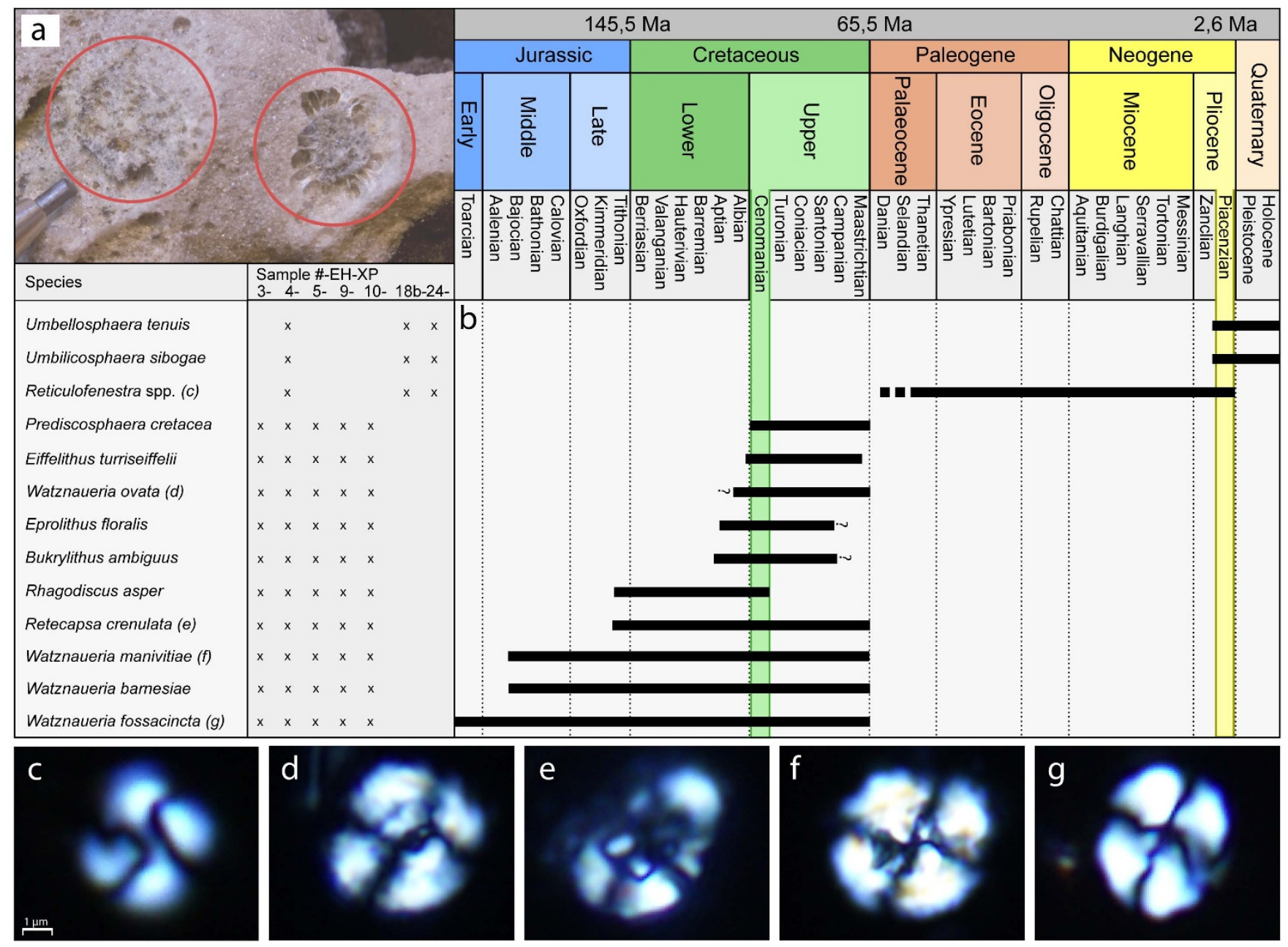

Figure $2 \mid$ Stratigraphic range chart for identified fossil taxa. (a) Examples of sedimentary relicts in El Hierro xeno-pumice. (b) Temporal record of Calcareous nannofossils in xeno-pumice. Four samples contain Jurassic to Cretaceous species that define a common Albian/Cenomanian age $(\sim 100 \mathrm{Ma})$. Two samples contain two Pliocene to recent species that co-occur with one Paleogene species that was extinct at the Neogene-Quaternary boundary, dating the youngest sedimentary relicts to $\sim 2.5 \mathrm{Ma}$ (Piacenzian). One sample shows a mixed age assemblage (see text for details). (c-g) Representative smear slides of identified taxa. (c): Reticulofenestra spp., (d): Watznaueria ovata, (e): Retecapsa crenulata, (f): Watznaueria manivitiae, (g): Watznaueria fassacincta.

cates a common Piacenzian age, as the latter group became extinct at the end of the Pliocene. This co-occurrence translates to an absolute age of $\sim 2.5 \mathrm{Ma}$ for the youngest fossil assemblage amongst the 2011 eruptive products. The apparent stratigraphic gap in the erupted sedimentary materials may indicate that an incomplete sedimentary or fossil record is present underneath El Hierro, which would not be surprising since the thickness of the sedimentary succession beneath the island is only $\leq 1 \mathrm{~km}^{15,17,18}$. Given that magma migrated laterally along the level of the pre-island sediments just prior to the onset of the 2011 eruption $^{21}$, it is also possible that lateral channel flow and associated sediment melting focussed in the central part of this $\leq$ $1 \mathrm{~km}$ sedimentary package. Indeed, El Hierro xeno-pumice are for the most part fused (light coloured pumiceous glass, Appendix A), testifying to their propensity for rapid melting and assimilation into the hot magma. Assuming that lateral channel flow applies, the sedimentary units most likely to survive as relicts in xeno-pumice would be the oldest and youngest, i.e., the stratigraphically lowest and highest sediments in the sub-El Hierro sedimentary pile.

Remarkably, the youngest fossil age recovered $(\sim 2.5 \mathrm{Ma})$ is in agreement with previous estimates for the onset of shield-building at El Hierro, inferred to be Pliocene to Quaternary on the basis of seismic reflection data ${ }^{17,18,22}$, and thus represents indeed the youngest pre-island sediment age recorded for the entire Canary archipelago.
Although the onset of volcanic activity at oceanic islands commonly lacks constraints due to inaccessibility of the earliest eruptive products, the age of sedimentary strata under El Hierro now provides a critical proxy to assess the lifespan of the present El Hierro edifice. Taking the youngest fossil age from our nannofossil suite to represent the change from a sedimentary depositional to a volcanic environment that terminated regular marine sedimentation at $\sim 2.5 \mathrm{Ma}$, and employing an estimated island volume of $\sim 10,500 \mathrm{~km}^{3}$ for the present El Hierro edifice, then a minimum mass eruption rate (magma flux) of $\geq 4.2 \times 10^{3} \mathrm{~km}^{3} / \mathrm{Ma}$ is derived (Appendix D). Established mass eruption rates for Canary shield volcanoes range from 4 to $9 \times 10^{3} \mathrm{~km}^{3}$ (ref. 27), and thus define the El Hierro estimate as typical for Canary volcanism.

The recent discovery of Early Cretaceous (Hauterivian; $133 \mathrm{Ma}$ ) submarine volcanic rocks at the El Hierro southern ridge ${ }^{7}$ apparently disagrees with the age progression of the onshore volcanic rocks and implies a potentially much earlier onset of volcanic activity at El Hierro and in the archipelago as a whole. Our new data now document Cretaceous $(\sim 100 \mathrm{Ma})$ and Pliocene $(\sim 2.5 \mathrm{Ma})$ sedimentary strata in the basement beneath El Hierro island. Our findings negate the notion of a) continuous volcanic activity since the Cretaceous or b) a lasting geographic rise between $\sim 100 \mathrm{Ma}$ and $\sim 2.5 \mathrm{Ma}$ in the vicinity of El Hierro, because the presence of a large volcanic complex 

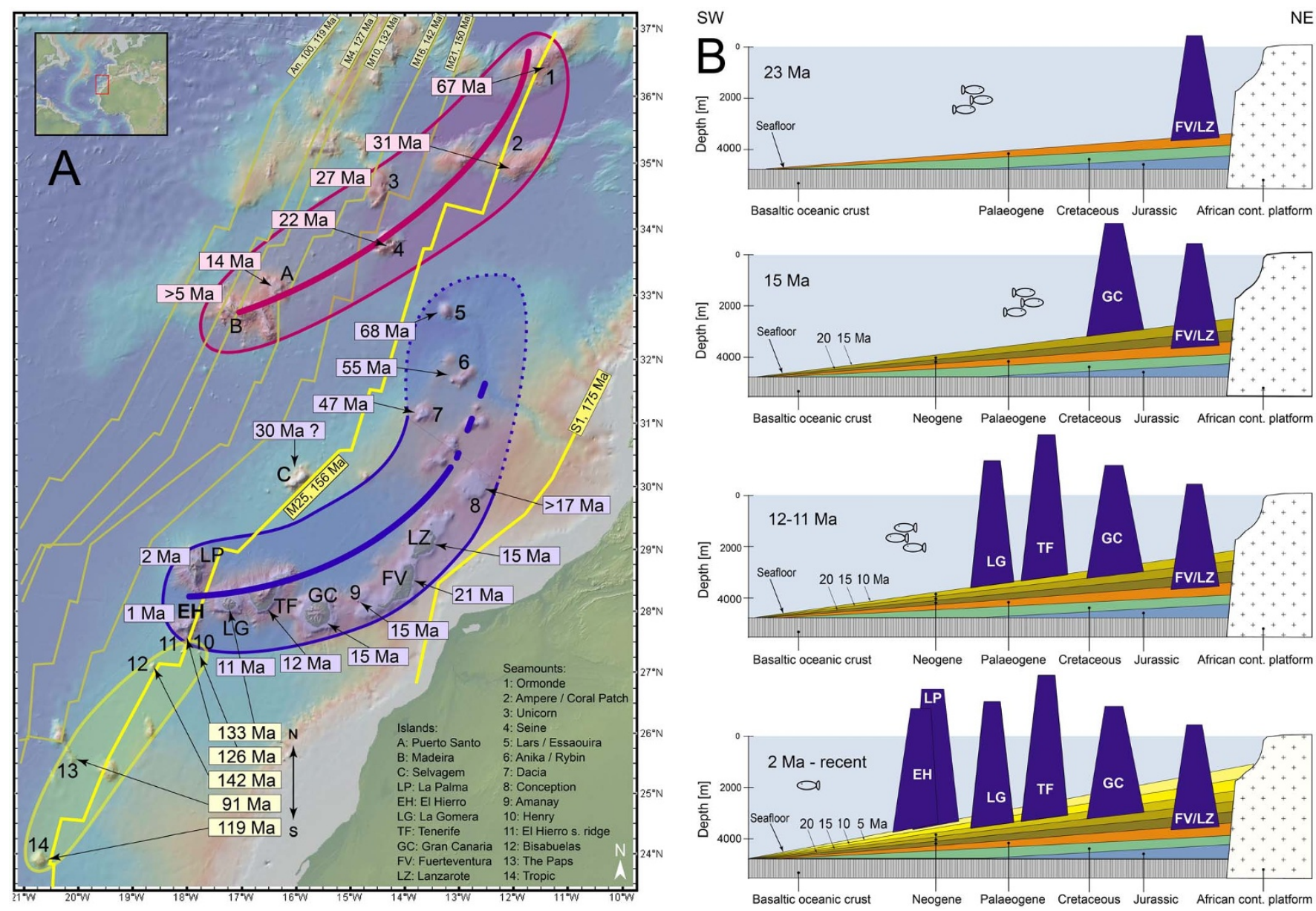

Figure $3 \mid$ (A): Map of Canary (blue) and Madeira (red) archipelagos, associated seamounts, and magnetic ocean floor anomalies (yellow) ${ }^{28}$. New and reported ages imply an east to west age progression for the Canary and Madeira archipelagos, whereas the Cretaceous seamounts to the south of the Canaries appear randomly age distributed. The new fossil ages imply a time window between Cretaceous and present-day Canary volcanism of $\sim 130 \mathrm{Ma}$ in the vicinity of El Hierro. (B): Schematic SW-NE cross section through the Canary archipelago (vertically exaggerated). The El Hierro nannofossils now identify the youngest sub-volcanic sedimentary strata $(\sim 2.5 \mathrm{Ma})$ in the west of the archipelago. (Map source: "GeoMapApp"; www.geomapapp.org) $)^{42}$.

since the Cretaceous cannot be reconciled with extensive detrital deposition at this site at the same time, nor with a lack of volcanic minerals in the sedimentary relicts recovered during the early days of the 2011/2012 eruption. The El Hierro sedimentary xenoliths instead imply that the recently recovered Cretaceous submarine volcanic rocks belong to a separate and older volcanic episode in the region, probably together with the extinct Cretaceous Henry seamount $(\sim 126 \mathrm{Ma})$ situated $\sim 40 \mathrm{~km}$ to the southeast of El Hierro ${ }^{27}$.

Indeed, considering the oldest available ages for the islands of the Canary and Madeira regions together with the magnetic ocean floor anomalies of the East-Central Atlantic (Figure 3), it becomes apparent that the Cretaceous seamounts south of the Canaries show a marked alignment with the ocean floor magnetic anomalies ${ }^{28}$. The Canary and Madeira hot spot trends, in turn, show a curved age-progression from the oldest $(>60 \mathrm{Ma})$ to the youngest islands $(\sim 1 \mathrm{Ma})$ within each archipelago and the two age patterns are moreover broadly parallel, thus mirroring the rotational movement of the African plate over the last $\sim 60 \mathrm{Ma}^{4}$. The Cretaceous seamount alignment is almost orthogonal to the curved Canary trend as are the magnetic ocean floor anomalies that derive from initial seafloor spreading during the opening of the Central Atlantic (e.g. M25). Notably, the internal distribution of the Cretaceous seamounts does not follow a clear age progression as observed in the Canary archipelago, but rather a seemingly random age distribution that is typical of fracture-controlled volcanism ${ }^{29}$. Our age data now resolve a $\sim 30 \mathrm{Ma}$ time window between the formation of the
$133 \mathrm{Ma}$ Cretaceous volcanic rocks southesast of El Hierro and the onset of subsequent sedimentation at $\sim 100 \mathrm{Ma}$, and, moreover, a $\sim 130$ Ma window between Cretaceous volcanic activity and the onset of El Hierro volcanism (at $\leq 2.5 \mathrm{Ma}$ ). The Cretaceous seamounts, including the fragment recorded from the submarine part of $\mathrm{El}$ Hierro, are thus related to an earlier, probably fracture-controlled magmatic episode unrelated to the genesis of the Canary archipelago (Figure 3). We suggest that the present-day El Hierro volcanism likely uplifted a block of Cretaceous volcanic rocks to the ocean floor in a process similar to the uplift event which gave rise to the now onshore exposed 'submarine' basal complexes of Fuerteventura and $\mathrm{La}$ Palma ${ }^{9,12,30}$

Most importantly, however, the erupted El Hierro sedimentary relicts provide crucial support for an east-west age progression for the onset of volcanism in the Canary archipelago by demonstrating unequivocally that the youngest pre-island sediment is located beneath El Hierro. The fossil evidence from El Hierro therefore concludes the current debate on the origin of the Canary Islands and reinstates a mantle-plume as the most plausible cause of volcanism in the Canary Islands.

1. Morgan, W. J. Convection Plumes in the Lower Mantle. Nature 230, 42-43 (1971).

2. Hoernle, K. \& Schmincke, H.-U. The Role of Partial Melting in the 15-Ma Geochemical Evolution of Gran Canaria: A Blob Model for the Canary Hotspot. J. Petrol. 34, 599-626 (1993). 
3. Carracedo, J. C. et al. Hotspot volcanism close to a passive continental margin: the Canary Islands. Geol. Mag. 135, 597-604 (1998).

4. Geldmacher, J., Hoernle, K., van den Bogaard, P., Duggen, S. \& Werner, R. New ${ }^{40} \mathrm{Ar} /{ }^{39} \mathrm{Ar}$ age and geochemical data from seamounts in the Canary and Madeira volcanic provinces: Support for the mantle plume hypothesis. Earth Planet. Sci. Lett. 237, 85-101 (2005).

5. Anguita, F. \& Hernan, F. A propagating fracture model versus a hot spot origin for the Canary Islands. Earth Planet. Sci. Lett. 27, 11-19 (1975).

6. Anguita, F. \& Hernan, F. The Canary Islands origin: a unifying model. J. Volcanol. Geoth. Res. 103, 1-26 (2000)

7. van den Bogaard, P. The origin of the Canary Island Seamount Province - New ages of old seamounts. Sci. Rep. 3, 1-7 (2013)

8. Lancelot, Y. et al. Initial Reports of the Deep Sea Drilling Project Volume 41 site 369, Abidjan, Ivory Coast to Malaga, Spain. Gardner, J., Herring, J. (eds.) (U.S. Government Printing Office, Washington 1977).

9. Robertson, A. H. F. \& Stillman, C. J. Late Mesozoic sedimentary rocks of Fuerteventura, Canary Islands: Implications for West African continental margin evolution. J. Geol. Soc. London 136, 47-60 (1979).

10. von Rad, U. et al. Initial Reports of the Deep Sea Drilling Project Volume 47 site 397, Part 1, Las Palmas, Canary Islands to Vigo, Spain. Laughter, F. H., Fagerberg, E. M. (eds.) (U.S. Government Printing Office, Washington 1979).

11. Hoernle, K. Geochemistry of Jurassic Oceanic Crust beneath Gran Canaria (Canary Islands): Implications for Crustal Recycling and Assimilation. J. Petrol. 39, 859-880 (1998).

12. Steiner, C., Hobson, A., Favre, P., Stampfli, G. M. \& Hernandez, J. Mesozoic sequence of Fuerteventura (Canary Islands): Witness of Early Jurassic sea-floor spreading in the central Atlantic, Geol. Soc. Am. Bull. 110, 1304-1317 (1998).

13. Hansteen, T. H. \& Troll, V. R. Oxygen isotope composition of xenoliths from the oceanic crust and volcanic edifice beneath Gran Canaria (Canary Islands): consequences for crustal contamination of ascending magmas. Chem. Geol. 193, 181-193 (2003).

14. Aparicio, A., Bustillo, M. A., Garcia, R. \& Arana, V. Metasedimentary xenoliths in the lavas of the Timanfaya eruption (1730-1736, Lanzarote, Canary Islands): metamorphism and contamination processes, Geol. Mag. 143, 181-193 (2006).

15. Urgeles, R., Canals, M., Baraza, J. \& Alonso, B. Seismostratigraphy of the western flanks of El Hierro and La Palma (Canary Islands): a record of Canary Island volcanism. Mar. Geol. 146, 225-241 (1998).

16. Ranero, C. R., Torne, M. \& Banda, E. Gravity and Multichannel Seismic Reflection Contraints on the Lithospheric Structure of the Canary Swell. Mar. Geophys. Res. 17, 519-534 (1995).

17. Collier, J. S. \& Watts, A. B. Lithospheric response to volcanic loading by the Canary Islands: constraints from seismic reflection data in their flexural moat. Geophys. J. Int. 147, 660-676 (2001).

18. Montesinos, F. G., Arnoso, J., Benavent, M. \& Vieira, R. The crustal structure of El Hierro (Canary Islands) from 3-D gravity inversion. J. Volcanol. Geoth. Res. 150, 283-299 (2006).

19. Carracedo, J. C. et al. The Ongoing Volcanic Eruption of El Hierro, Canary Islands. Eos Trans. Am. Geophys. Union. 93, 89-90 (2012).

20. Pérez-Torrado, F. J. et al. La erupción submarina de La Restinga en la isla de El Hierro, Canarias: Octubre 2011-Marzo 2012. Estud. Geol. 68, 5-27 (2012).

21. Gonzalez, P. J. et al. Magma storage and migration associated with the 2011-2012 El Hierro eruption: Implications for crustal magmatic systems at oceanic island volcanoes. J. Geophys. Res.-Sol. Ea. 118, 4316-4377 (2013).

22. Gee, M. J. R., Masson, D. G., Watts, A. B. \& Mitchell, N. C. Offshore continuation of volcanic rift zones, El Hierro, Canary Islands. J. Volcanol. Geoth. Res. 105 107-119 (2001).

23. Troll, V. R. et al. Floating stones off El Hierro, Canary Islands: xenoliths of preisland sedimentary origin in the early products of the October 2011 eruption. Solid Earth 3, 97-110 (2012)

24. Bown, P. R. (Ed.). Calcareous Nannofossil Biostratigraphy. (British Micropalaeontological Society Series, Kluwer Academic Publishers, Cambridge, 1999).

25. Perch-Nielsen, K. Mesozoic and Cenozoic calcareous nannofossils. H, M., Saunders, J. B. \& Perch-Nielsen, K. (Eds.), 329-554, (Plankton Stratigraphy. Cambridge University Press, 1989).

26. Schmincke, H.-U. \& Sumita, M. Volcanic evolution of Gran Canaria reconstructed from apron sediments: Synthesis of VICAP project drilling. Proc. Ocean Drill. Prog. Sci. Results 157, 443-469 (1998).

27. Klügel, A., Hansteen, T. H., van den Bogaard, P., Strauss, H. \& Hauff, F. Holocene fluid venting at an extinct Cretaceous seamount, Canary archipelago. Geology 39, 855-858 (2011).

28. Müller, R. D., Roest, W. R., Royer, J.-Y., Gahagan, L. M. \& Sclater, J. G. Digital isochrones of the world's ocean floor. J. Geophys. Res. 102, 3211-3214 (1997).

29. Feraud, G., Kaneoka, I. \& Allegre, C. J. K/Ar ages and stress pattern in the Azores: Geodynamic implications. Earth Planet. Sci. Lett. 46, 275-286 (1980).
30. Staudigel, H., Feraud, G. \& Giannerini, G. The history of intrusive activity on the island of La Palma (Canary Islands). J. Volcanol. Geoth. Res. 27, 299-322 (1986).

31. Aparicio, A., Tassinari, C. C. G., Garcia, R. \& Arana, V. Sr and Nd isotope composition of the metamorphic, sedimentary and ultramafic xenoliths of Lanzarote (Canary Islands): Implication for magma sources, J. Volcanol. Geotherm. Res. 189, 143-150 (2010)

32. Bustillo, M. A., Nishimura, A., Arana, V. \& Hattori, I. (1994). Palaeocene radiolarians hosted in holocene lavas of Lanzarote (Canary Islands). Geobios 27, 181-188 (1994)

33. Guillou, H., Carracedo, J. C., Perez Torrado, F. \& Rodriguez Badiola, E. K-Ar ages and magnetic stratigraphy of a hotspot-induced, fast grown oceanic island: El Hierro, Canary Islands. J. Volcanol. Geotherm. Res. 73, 141-155 (1996).

34. Guillou, H., Carracedo, J. C., Paris, R. \& Torrado, F. J. P. Implications for the early shield-stage evolution of Tenerife from K/Ar ages and magnetic stratigraphy. Earth Planet. Sci. Lett. 222, 599-614 (2004).

35. Klügel, A., Schmincke, H.-U., White, J. D. L. \& Hoernle, K. A. Chronology and volcanology of the 1949 multi-vent rift-zone eruption on La Palma (Canary Islands). J. Volcanol. Geotherm. Res. 94, 267-282 (1999).

36. Martinez del Olmo, W. \& Buitrago, J. B. Sedimentacion y volcanismo al este de las islas de Fuerteventura y Lanzarote (Surco de Fuster Casas). Geogaceto 32, 51-54 (2002).

37. Paris, R., Guillou, H., Carracedo, J. C. \& Perez-Torrado, F. J. Volcanic and morphological evolution of La Gomera (Canary Islands), based on new K-Ar ages and magnetic stratigraphy: Implications for oceanic island evolution. J. Geol. Soc. 162, 501-512 (2005).

38. Robertson, A. H. F. \& Stillman, C. J. Submarine volcanic and associated sedimentary rocks of the Fuerteventura Basal Complex, Canary Islands. Geol. Mag. 116, 203-214 (1979a).

39. Robertson, A. H. F. \& Bernoulli, D. Stratigraphy, Facies, and Significance of Late Mesozoic and Early Tertiary Sedimentary Rocks of Fuerteventura (Canary Islands) and Maio (Cape Verde Islands). In: Geology of the Northwest African Continental Margin, Springer, Heidelberg Berlin (1982).

40. Sanchez-Guzman, J. \& Abad, Y. J. Sondeo Geotermico Lanzarote-1. Significado Geologico y Geotermico. Anales de Fisica 82, 102-109 (1986).

41. Schmincke, H.-U. et al. Proceedings of the Ocean Drilling Project, Initial Reports, 157, Gran Canaria and Madeira Abyssal Plain. Fox, C. O. (ed.) (College Station, Texas 1995.

42. Ryan, W. B. F. et al. Global Multi-Resolution Topography synthesis, Geochem. Geophys. Geosyst, 10, Q03014, doi:10.1029/2008GC002332 (2009).

\section{Acknowledgments}

We are grateful to Andreas Klügel, Marc-Antoine Longpre, Sebastian Wiesmaier, Ulrich Kueppers, Carmela Freda and Carmen Lopez for discussion on the topic. Jarek Majka and Iwona Klonowska are thanked for help with Perplex modelling, Michael Streng for help with sample selection for fossil identification, and Harri Geiger and Tobias Mattsson for help with figure preparation and formatting. This research is supported by the Royal Swedish Academy of Sciences (KVA), the Center for Natural Disaster Sciences (CNDS) at Uppsala University the Jänes Foundation and through the Swedish Science Foundation (VR)

\section{Author contributions}

The study was initiated by V.R.T., M.C., and J.C.C. Sampling was carried out by V.S. Fossil identification was performed by M.C. and J.F. Data compilation and presentation was led by K.Z. Figure 2 was provided by M.C. and J.F. The manuscript was jointly written by K.Z., V.R.T., and F.M.D. with contributions from M.C., J.F., J.C.C., V.S., F.C.M., and S.B., and forms part of the doctoral thesis of K.Z. at Uppsala University.

\section{Additional information}

Supplementary information accompanies this paper at http://www.nature.com/ scientificreports

Competing financial interests: The authors declare no competing financial interests

How to cite this article: Zaczek, K. et al. Nannofossils in 2011 El Hierro eruptive products reinstate plume model for Canary Islands. Sci. Rep. 5, 7945; DOI:10.1038/srep07945 (2015).

This work is licensed under a Creative Commons Attribution-NonCommercialShareAlike 4.0 International License. The images or other third party material in this article are included in the article's Creative Commons license, unless indicated otherwise in the credit line; if the material is not included under the Creative Commons license, users will need to obtain permission from the license holder in order to reproduce the material. To view a copy of this license, visit http:// creativecommons.org/licenses/by-nc-sa/4.0/ 